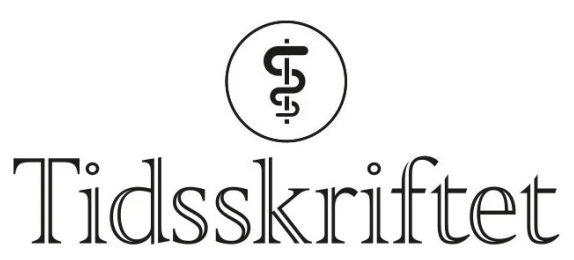

DEN NORSKE LEGEFORENING

\title{
Statsråd Støre og sjukehuspolitikken
}

LEDER

\section{RUNE HEGGEDAL}

Rune Heggedal (f. 1960) er avdelingsoverlege i anestesiologi ved Kirurgisk klinikk, Volda sjukehus. Forfattaren har fylt ut ICMJE-skjemaet og oppgjev ingen interessekonfliktar.

Email: rune.heggedal@tussa.com

\section{Føretaksorganiseringa av sjukehusa har ført til svekka verdiforankring, manglande auge for pasienten og dårleg samsvar mellom ressurstilgang og oppgåver. Statsråd Støre lovar endring, men ingen ny kurs?}

30. januar 2013 heldt helsestatsråd Støre ein tale til sjukehusa. Talen har fått mykje merksemd (1 1$)$ - alt frå god omtale til å bli karakterisert som keisarens nye klede. Altså lite nytt. Når vi skrellar bort elegant retorikk og positive mål og ambisjonar for helsetenesta som vi alle kan slutte oss til, kva står då att? Kva er det han ikkje seier?

Satsing på felles nasjonale IKT-løysingar er tvingande nødvendig. Sterkare regional samordning, fjerning av unødvendig og ressursøydande rapportering likeeins. Når Støre i kapittelet om betre leiing vil gå til kjernen i verdiskapinga i sjukehuset - møtet med pasienten - er dette flott, men på høg tid! Dersom dette fører til sterkare vekt på fag og på forsvarleg organisering av pasienttilbodet, lokal stadleg leiing og bortfall av uønska tverrgåande avdelingar, då vil det føre oss framover.

Støre seier lite om økonomi i talen. Regjeringa har tidlegare påstått at Noreg er i verdstoppen når det gjeld løyvingar til sjukehusa. Dette er ikkje sant. Professor i helseøkonomi Bjarne Jensen har påvist at den norske ressursbruken på sjukehussektoren er heilt gjennomsnittleg for europeiske land (2). Påstanden om høg ressursbruk har blitt lagt til grunn for oppfatninga om at sjukehussektoren har vore dårleg organisert og har dermed vorte eit argument for omorganisering og sentralisering. Ein kan få inntrykk av at ein i Helse- og omsorgsdepartementet og i dei regionale helseføretaka lir av alvorlege vrangførestellingar om at årlege og uendelege rasjonaliseringsgevinstar i sjukehusa er mogeleg. I praksis betyr dette at kvar helsearbeidar må jobbe litt raskare for kvart år. I tillegg til pasientarbeid kjem omfattande rapporteringsrutinar, klagesaker, tilsyn frå ulike kontrollinstansar, auka forventningar om informasjon til pasient og pårørande samt - ikkje minst - det som stel mest tid og energi: Dei stadige endringsprosessane. I klinisk arbeid vil det for høgkompetente helsearbeidarar vere minst like viktig med meir tid til pasientmøtet for å kunne heve kvaliteten på pasientbehandlinga som det er med kampanjar for kvalitet. 
Statsråden foreslår eit nasjonalt føretak for planlegging av sjukehusbygg. Eg meiner at også sjølve finansieringa av nye sjukehus burde bli trekt ut av den daglege drifta. Slik føretaka er finansierte i dag, er det lagt opp til at det må kuttast i driftsbudsjetta, altså

i pasientbehandlinga, for å kunne gje rom for nye sjukehusbygg. Det er også store ulikskapar mellom helseregionane, alt etter fordelinga av gamal og ny bygningsmasse.

Dette må endrast, til dømes slik at staten eig alle sjukehusbygg gjennom eit eige selskap.

Statsråden forsvarar organiseringa i lokale og regionale helseføretak. Eg meiner det er sider ved denne organiseringa som er sjølve rota til mange av dei problema vi strir med. Det er innført ein lydnadskultur, der lojalitet oppover er det viktigaste for alle leiarar. Lojaliteten til pasienten har lågare prioritet enn lojaliteten til økonomi og til organisasjonen sjølv. Denne kjølige teknokratiske rasjonalitetsideologien har sin eigen logikk, med merkantilt språk og regelstyrt formalisme som gjennomsyrer heile organisasjonen. Vi opplever svekka verdiforankring, ikkje berre på føretaksnivå, men også i den kliniske verksemda.

Lønsemdvurderingar påverkar både klinisk prioritering og praksis. Omgrepet «medisinsk forsvarleg verksemd» er relativisert og sett til side og ikkje lenger eit avgjerande fundament for spesialisthelsetenesta.

Organiseringa av sjukehussektoren er under kraftig debatt over heile landet. Striden har i det siste vore særleg sterk i Oslo og i Tromsø. Det har oppstått ei djup kløft mellom fagfolka og dei leiande helseteknokratane. Omfattande endringar er planlagde og også gjennomførte - mot sterke faglege åtvaringar frå røynde overlegar. I Oslo synest liv og helse å ha gått tapt fordi leiinga ikkje lytta til fagfolka, men berre til endringsideologane og konsulentar som ikkje forstår samanhengen mellom alle dei faktorane som må vere på plass for at vi skal ha eit godt helsetilbod. Både ved Oslo universitetssykehus og Universitetssykehuset Nord-Norge ytrar dei tilsette sterk mistillit til sjukehusleiinga.

Også elles i landet er det strid. Ettersom Soria Moria-avtalen ikkje gjev rom for nedlegging av lokalsjukehus, har fleire regionale helseføretak freista å løyse denne utfordringa ved å tøme sjukehusa for innhald. Når den kirurgiske verksemda ved eit lokalsjukehus vert fjerna, er det ikkje lenger eit sjukehus. Kvaliteten på det gjenverande tilbodet vert kraftig svekka fordi ein manglar breiddekompetanse i vakt, rekrutteringa fell bort og institusjonen vil forvitre slik at det som før var eit sjukehus ikkje lenger trygt vil kunne ta i mot akuttpasientar. Det hjelper ikkje å gje nyskapinga optimistiske namn, som «framtidas lokalsjukehus». Slike prosessar er uverdige, både i eit fagleg og i eit demokratisk perspektiv, og har ført til alvorleg svekka omdøme for føretak og regjering.

Føretaksstrukturen er lite elastisk og nyttar dårleg utviklinga i andre samfunnsektorar. Det synest vanskeleg å finne løysingar på problem som ikkje oppdragsdokumentet gjev svar på, som nye vegar eller "uventa» konsekvensar av nedleggingsvedtak i ein annan helseregion. I grenseområdet mellom Helse Vest og Helse Midt-Norge har slike endringar ført til at nordfjordingane reiser kortaste vegen ut av eigen region til Volda og Sunnmøre for kirurgisk behandling. For føretaka er pasientstraumen over grensa uønska og tilsynelatande eit uløyseleg problem, trass i halvert reisetid for sjuke og pårørande. Helse Vest vil halde på pasientane, medan Helse Midt-Norge ikkje vil trø i naboens bed, dei viser til at dei ikkje har ansvar. Departementet har også blitt utfordra til å løyse flokane, utan å gjere noko så langt.

Meiner statsråden at dette er å sette pasienten i sentrum? Er det god samfunnsøkonomi? Er det i samsvar med allmenn samfunnsmoral?

Etter meir enn ti år med føretaksorganisering ynskjer det store fleirtalet av tilsette og tre av fire leiarar (3) ein ny kurs for styringa av sjukehusa. Vi ynskjer oss sterkare vekt på pasienten og at medisinskfagleg forsvarleg praksis igjen vert det viktigaste for organisering av sjukehusa. Dette betyr ikkje at økonomien kjem ut av kontroll, men at ressursstyringa vert eit middel for ei god helseteneste og ikkje eit mål i seg sjølv. Statsråd Støre ynskjer seg 
endringar til beste for pasientane. Då kan han ikkje berre spørje om råd i departementet og i dei regionale føretaka. Han må også skaffe seg faste lyttepostar hos røynde legar og andre som driv dagleg klinisk arbeid. Berre nedanfrå kan ny tillit byggast.

Publisert først på nett.

\section{LITTERATUR}

1. Støre JG. Politiske mål og forventninger til spesialisthelsetjenesten. Tale til sykehusene 30.1.2013. Oslo: Helse- og omsorgsdepartementet, 2013.

2. Ystad V. Knuser mytar om helsevesenet. Dag og Tid 22.2.2013. www.dagogtid.no/nyhet.cfm? nyhetid=2496 (4.3.2013).

3. Hippe JM, Trygstad SC. Ti år etter. Ledelse, ansvar og samarbeid i norske sykehus. FAFO-rapport 2012: 57. www.fafo.no/pub/rapp/20284/20284.pdf(4.3.2013).

Publisert: 19. mars 2013. Tidsskr Nor Legeforen. DOI: 10.4045/tidsskr.13.0233

(C) Tidsskrift for Den norske legeforening 2023. Lastet ned fra tidsskriftet.no 26. april 2023. 